\title{
Propaganda, Literature and a Television Mini-Series: Representations of Roger Casement in Germany, 1916- 2016
}

\author{
Fergal Lenehan \\ Friedrich-Schiller University of Jena, Germany
}

Copyright (c) 2018 by Fergal Lenehan. This text may be archived and redistributed both in electronic form and in hard copy, provided that the author and journal are properly cited and no fee is charged for access.

\begin{abstract}
A fairly extensive German-language tradition of depicting Roger Casement exists that has, until now, not been surveyed by cultural historians. Three distinct strands of Casement representation dominate, and often intertwine: 1) Casement as an international humanitarian, 2) Casement as an extreme Irish nationalist, and 3) Casement as a gay martyr. These narratives have been highly dependent on the socio-political context and the needs of the creators. Thus Casement has been depicted as a rabid Irish nationalist within German antiBritish propaganda texts during World War One and Two, but also as an international humanitarian who practiced a liberationist nationalism during the years of the democratic Weimar Republic, while the Casement story has in addition been mined to humanise gay men in post-War West Germany.
\end{abstract}

Key Words. Roger Casement, Germany, nationalism, 1916, television, propaganda.

Resumen. Existe una tradición ya bastante prolija en cuanto a la representación de Roger Casement que no ha sido lo suficientemente estudiada por los historiadores de la cultura. Predominan tres líneas en la representación de Casement, líneas que a menudo se entrecruzan: 1) Casement como un activista humanitario de ámbito internacional, 2) Casement como un fanático nacionalista irlandés, y 3) Casement como un mártir del movimiento gay. Estos relatos han estado directamente influidos por el contexto sociopolítico del momento, así como por los objetivos de los autores que han tratado el tema. De esta forma, Casement se ha presentado como un ferviente nacionalista irlandes en una serie de textos propagandísticos alemanes de carácter antibritánico durante las dos guerras mundiales del siglo XX, pero también como un activista humanitario de ámbito internacional, que luchó por un tipo de nacionalismo liberacionista, durante los años de la República Democrática de Weimar. Al mismo tiempo la historia de Casement ha sido empleada para humanizar la imagen del colectivo gay en la Alemania Occidental de la posguerra. 
Palabras clave. Roger Casement, Alemania, nacionalismo, 1916, televisión, propaganda.

\section{Introduction: Representations of Casement}

Historians have remained fascinated by Roger Casement (1864-1916). ${ }^{1}$ From an Ulster Protestant military family, Casement became a British diplomat, coming to wider prominence for his exposure of inhuman practises in the Congo and the Amazonian Putumayo district. The Knighthood he received in 1911 did not stop him, however, from becoming an ardent Irish nationalist. He travelled to Germany in 1914 in the hope of acquiring arms for rebellion, while his attempt to assemble an Irish Brigade from Irish prisoners of war in the British Army in Germany was not wholly successful. Landing from Germany off the Kerry coast in 1916 prior to the Easter Rising, he was captured, tried for treason and executed. Before the conclusion of Casement's trail, rumours of diaries he had supposedly written, detailing extensive homosexual encounters, were widely circulated. While the authentic nature of these "Black Diaries" is still heatedly discussed (Dudgeon, "Casement"), as the Casement biographer Angus Mitchell suggests: "Irrespective of the question of their authenticity, it is now universally agreed that the Black Diaries were integral to a smear campaign conjured up in 1916 to railroad Casement to the gallows" ("Roger Casement" 34).

Casement has also fascinated artists and writers. He has featured in poetry by W.B. Yeats, paintings by Sir John Lavery, a 1960 television drama based on his trial was screened in Britain by Granada television, a number of recent RTE radio plays and documentaries have centred on Casement, while he was also the principal figure in a widely-read 2010 novel by Peruvian Nobel Prize winner Mario Vargas Llosa (Dudgeon, "Roger Casement"). 2016, and the commemoration of the 1916 Rising, saw art installations dealing with Casement's life (Dunne), a Casement dance show (Lucy), and musician Gavin Friday's 'The Casement Sonata' (McClancy). Two Roger Casement film projects, from the 1930s and early 21st century, failed to materialise however (Dudgeon, "Roger Casement"). ${ }^{2}$ According to Jeffrey Dudgeon ("Roger Casement") Casement's sheer complexity means he has not been portrayed in a movie intended for cinema, Casement being: "martyr, diplomat, defector, patriot, poet, traitor, humanitarian, homosexual, pederast, some imply paedophile, victim, saint, Irish nationalist and adopted Ulsterman" ("Roger Casement"). Art critic Aidan Dunne argues, on the other hand, that Casement's multifaceted complexity is what actually draws artists to him, as "different factions draw from the complex layers of his history and character a Casement who suits their own preferences and prejudices"; it is "Casement's ambiguity that ultimately appeals to artists and writers" (Dunne).

Thus, there remains a complex and multifaceted tradition of representing Casement in words and images, largely in the English-speaking world. Casement's involvement with imperial Germany was also central to his story and it is, then, not surprising to find that there also exists a fairly extensive German-language tradition of depicting Casement; a tradition that has, until now, not been surveyed by cultural historians. Portrayals of Casement in Germany are very much influenced by the context of their production; aspects of his biography and character are highlighted that help to serve the specific interests of authors and television makers of particular times in German and West German history (East German representations of Casement do not appear to exist). Three distinct strands of Casement representation dominate, and sometimes intertwine: 1) Casement as an international humanitarian, 2) Casement as an extreme Irish nationalist, and 3) Casement as a gay martyr. 


\section{World War One: A Humanitarian anti-Imperialist and a Nationalist Saint}

Some of the first representations of Casement in Germany appeared in the journal Irische Blätter $^{3}$ (Irish Pages); edited by Georges Chatterton-Hill, a German-based Anglo-Indian Catholic and sociologist and, at least at this stage of his life, an Irish nationalist due, probably, to some Irish heritage. In a 1917 article for this journal, the Vienna-based Celtic scholar Julius Pokorny writes of himself and Casement as bonding in Hamburg due to their shared nationalisms (93), while Casement "supported always the poorest of the poor, and did what he could for the poverty-stricken western districts of Ireland" (94). ${ }^{4}$ An article by the journal's editor in August 1917 castigates constitutional nationalism, especially "Judas John Redmond". The author links Casement's Irish nationalism quite explicitly to his earlier humanitarian work, which, he believes, was dedicated to the victims of both imperialism and capitalism (Chatterton-Hill 324). Casement's life, for Chatterton-Hill, retains an almost Christ-like role-model function: "Roger Casement still lives. His spirit will always live. We find him in all of the endeavours to find a path out of the terrible devastation and destruction of the world catastrophe, the path that will lead to ethically higher circumstances" (332). Thus, Casement is given an almost metaphysical stature as symbolic of a better, more just world. Agatha M. Bullet, a German-based Irish-American active in Irish nationalist propaganda circles in Berlin, also sees Casement's international humanitarian work and his Irish nationalism - in a pamphlet from 1917 - as two distinct aspects of the same antiimperialist project (Bullet 5). India is "that greater Ireland beyond the seas, whose sufferings he [Casement] knew and understood so well" (21), while: "We Irish and we Indians have suffered the tortures of deepest hell. But we know that these tortures shall have an end. While he lived, Casement pleaded for us earnestly and well" (24). Thus, Casement's life and humanitarian legacy is used here as an argumentative tool in an attempt to create an IrishIndian, anti-British and anti-imperialist solidarity.

Casement's collected writings were published in German translation in 1917, with a small number of anonymous ${ }^{5}$ accompanying texts contextualising the author in a distinctly anti-British manner for the German wartime reader. Casement's life story is a case study in the "poison arrows of British slander" sent "secretly to anyone who has the courage to be seen as our [Germany's] friend". ${ }^{6}$ Casement's life, it is implied, may be seen as an example for Germans to follow, as he gave up everything to save his "Volk, oppressed by strangers", his "abused, scorned and slandered Irish Heimatland". Casement's humanity is seen in his attempts to keep Ireland out of the war to stop "unnecessary blood shed": "As in the Congo and the Amazon, the possibility of reducing the lot of the oppressed was always his goal". 8 Not least, however, Casement's actions helped the German war effort directly as troops destined for the western front were sent instead to Ireland "due to fears of a German landing". ${ }^{9}$ Thus, Casement's Irish nationalism, his humanitarian record and the help he gave to the German wartime effort are seen as existing on the same moral and ethical plane, as helping the oppressed against the oppressor; with Britain very much seen as the oppressor, while Germany is allied with the oppressed, here in an Irish form.

The most extensive Casement representation from this time is to be seen in a book by Franz Rothenfelder called Casement in Deutschland (1917). Rothenfelder, a little-known German nationalist and Catholic writer from Bavaria who also published war poetry during this time, revisits the stations of Casement's time in Germany in an astonishingly sentimental manner. Casement is depicted, quite literally, as a saintly and Christ-like figure. ${ }^{10}$ Casement was, according to Rothenfelder, often sickly but also displayed supernatural strength $(15 ; 16$; 47; 51; and 61); material things were irrelevant to the Irishman and he lived in poor conditions, yet also contributed generously to other people (17; and 19); Casement loved 
children (17); his Irish homeland (15; and 38) and Germany, especially Bavaria (20; 21; and 41); while he hated England "like all Irishmen" (30). Casement also loved his enemies: Rothenfelder describes how Casement spoke well of and defended British Foreign Secretary Edward Grey as a noble man (18; and 22), despite Grey being seen in Germany as the epitome of British evil (18).

Rothenfelder argues that from Casement's death something new will arise, namely a quasi-spiritualized German-Irish brotherly sense of togetherness. German-American and Irish-American friendship will act, Rothenfelder believes, as a template for this (75). This German-Irish friendship will, however, be enshrined by Casement's death and suffering. Although now deceased, "sir Roger became alive after his death in all German hearts" (63); "yes, they killed Casement, but the ideal for which he suffered and died cannot be killed by England" (66). "Ireland's freedom is a holy thing"; while "the inheritors of the Irish Brigade are us. Our Lord will complete, what Casement began" (76). Thus, God is here seen as on the side of Germany, Ireland and Roger Casement. Rothenfelder's text ends with further Christlike imagery merging with the image of German and Irish cooperation, as Casement's death was for the greater good of both the Irish and the German nations: "His death made the Irish and German Volk into brother nations. A common hero and martyr unite us. He also died for us" (124). Thus, bizarre religious allegories abound in this anti-British work of propaganda that looks to establish a unique Irish-German friendship.

\section{Weimar Republic: Gunrunning Adventures and a Humanitarian Saint}

The first representation of Casement in the post-World War One Weimar Republic-era came in a book by Karl Spindler. Spindler was a German naval officer who had undertaken a highly secret mission to Ireland in conjunction with Casement, aboard a German ship disguised as the Norwegian merchant ship the Aud. Spindler was to meet the submarine containing Casement off the Kerry coast, but the meeting never took place and he scuttled the Aud in Cork Harbour. Spindler details these events and his own time in Britain as a prisoner of war, calling his book a "real-life adventure story" (7), which be believes will appeal especially to youthful readers. Casement plays only a minor role in Spindler's text, appearing simply as an avid nationalist. Spindler calls him, somewhat disingenuously, a "glowing patriot who hated England to the very marrow of his bones". ${ }^{11}$ Casement is also called the "well-known leader of the Irish Sinn Féin" (17), and is given, thus, more political responsibility than he probably really possessed.

Casement had given the American scientist Charles E. Curry responsibility for some of his German papers before he left for Ireland in 1916. Curry subsequently published some of Casement's diaries in a Munich edition in 1922. In an accompanying text Curry contextualises Casement's life. An intermingling of Casement's international humanitarianism and Irish nationalism (Curry 11), and Casement as a human catalyst for an Irish-German friendship, are present again (16); a continuation thus of the line of argument inherent to the World War One texts.

The most substantial representation of Casement during the pre-World War Two period, and probably the most important for Casement's then reputation as a humanist, ${ }^{12}$ came in the form of an essayistic biography by the now largely forgotten anti-colonial and antiFascist writer Balder Olden - published as Adolf Hitler came to power in 1933. Olden fled Germany after the Nazi take-over and ended up in Montevideo, where he died in 1949. In an autobiographical sketch from 1937 Olden explains the genesis of his Casement study. In the 1920s he had written and published a novelistic biography of the well-known German colonist of Africa Carl Peters, whom Olden describes here as a colonial "pre-Hitler Nazi" ("Mein Leben" 8). His depiction of Peters in his 1927 novel was full, he had believed, of 
"disgust" for its protagonist ("Mein Leben" 8). To Olden's dismay this novel became highly popular in nationalist circles and, in order not to become a celebrated author among those he despised, he thus wrote a biography of Casement, who, he writes, gave his life "to help the Congo Negros, the Putumayo Indians and the Irish, who were all deprived of their rights through torture and violence" ("Mein Leben" 8). Thus, Casement's international humanitarianism segues here also, though more reflectively than in earlier texts, into his Irish nationalism, with Casement perceived as a counterpoint to colonialism.

Similarly to Rothenfelder (1917), Olden describes Casement, quite literally, as a saint. For Rothenfelder, as we have seen, Casement is a saintly Christ-like figure whose death will enable a brotherly Irish-German nationalist collaboration. For Olden, Casement is a humanist saint:

If there were a church of pure humanity, it would have to canonise Roger Casement, because his whole life was a single struggle for the abused, the humiliated and the weak, and in these struggles he never scrutinized the power of the opponent, he never calculated the threat of danger, nor the sacrifice which he would have to make. ("Paradiese" 83-84)

Casement's actions in Africa and South America are described as those of someone who "suffers" from Gerechtigkeitsfanatismus: "justice fanaticism" (Olden, "Paradiese" 101). Olden later deals explicitly with Casement's Irish nationalism, asking the question: "Did this citizen of the world become a nationalist?" ("Paradiese" 165). Olden explains that Casement actually came from Ulster Protestant stock, that he was reared in a family loyal to Britain and the crown, rather than Ireland:

He changed sides from the oppressors to the oppressed, from the holders of power to the enslaved - he made the plight of Ireland his own, as he had done with the Congo Negros and later with the Indians. "Where there is strength, be always on the side of the weak" - that was his nationalism. ("Paradiese" 165).

Olden also explains that Casement was not the only Irish nationalist who made sure that "blood and origin" were not at the centre of their national ideas: Eamon De Valera - today "president of the Irish republic [sic]" - is "half of Spanish blood [sic]", while the "barricade fighter" Countess Markiewicz was Polish through marriage ("Paradiese" 166). Thus, Olden paints Casement as a selfless internationalist humanitarian, whose liberationist nationalism had little to do the "blood and soil" nationalism of the German National Socialist movement he so abhorred; agents of which would later ban his Casement biography. Olden also does not, interestingly, make any reference to Casement's possible homosexuality and the "Black Diaries", which played such a central role in the trial resulting in his death.

\section{National Socialist Germany: A Victim of the British Secret Service, an Example of Nationalist Selflessness and the Main Character in an anti-British Spy Thriller}

The controversial Irish writer Francis Stuart authored an anti-British text dealing with Casement in 1940, in conjunction with the German translator Ruth Weiland, who also translated three of Stuart's novels during World War Two (McCormack 27). ${ }^{13}$ Stuart, born in Australia to Ulster Protestant parents but who converted from an early age to Catholicism (and Irish nationalism), spent the war years teaching at a university in Berlin and, from 1942 to 1944, gave regular broadcasts for the Irland Redaktion; Nazi radio propaganda directed at Ireland. Stuart later denied accusations of anti-Semitism, stating that he did not support "the 
Holocaust or the Nazi regime in Germany" (Rasche 87). Stuart's Der Fall Casement (The Example of Casement) is inspired by W.J. Moloney's 1936 book, The Forged Casement Diaries. According to W. J. McCormack (27) Weiland's original plan was to publish a German translation of Moloney's book, however "Moloney unexpectedly refused permission". Stuart then produced his own work on Casement, together with Weiland, "with much of the work done by Weiland herself" (McCormack 27). Stuart and Weiland's book seeks to expose the evils of British Secret Service propaganda. According to Stuart, the British Secret Service from 1914 sought to damage Casement's reputation internationally, spreading rumours among the American and continental press that he was unstable, and later that he was in Berlin solely for monetary reasons (Stuart 79-86). The "Black Diaries", "produced" they argue by the Secret Service (Stuart, 1940: 94), were the final element in this British propaganda manoeuvre, the diaries depicting a man who was a "victim of his own perverted inclinations" (92).

The tone of the text is decidedly anti-British and Stuart/Weiland actually have relatively little to say about Casement himself. Casement was, however, "filled with the old Ulster tradition of a glowing nationalism" (Stuart 15), while anti-capitalist sentiment is also in evidence, as in the Congo Casement found evidence "that Ireland had to tear itself away from the growing control of capitalism and the unrestrained commercial spirit" (Stuart 16). Stuart and Weiland say little in relation to contemporary events in Ireland, but do mention the need to acquire the six counties of Northern Ireland for the Irish state (31). The text concludes rather chillingly with Stuart - or perhaps Weiland? - stating that a German victory, upon which Casement placed so much emphasis, is now "almost complete", while the final image of the text is of future German and Irish soldiers together at Casement's grave at Pentonville Prison in Britain, "one day, which is no longer very far away", paying homage to a "great patriot" "who has done so much to promote the friendship between our two nations" (110). Thus, the book ends with a fantasy of Nazi Germany's victory over Britain, which would also mean, at least within the mind of Stuart and/or Weiland, a victory for Ireland and the radical resuscitation of Casement's reputation.

In 1940 Weiland also edited a short book containing biographies of "Irish freedomfighters". Many of the authors were involved in the propaganda activities of the Irland Redaktion, while the journalist and academic Franz Fromme provides an article on Casement. ${ }^{14}$ Fromme had met Stuart in Dublin in 1939 (O’Donoghue: 42) and in 1940 was working for German intelligence. Unsurprisingly within the anti-British atmosphere of Nazi Germany in 1940, Fromme's Casement is deeply nationalist and anti-British (Fromme 1940: 53). Even in the service of British diplomacy, Casement "remained in his soul an Irishman whose hereditary and arch-enemy was England" (Fromme 54), while the "Black Diaries", though written in Casement's hand, were actually the words of the South American Armando Normand, Fromme argues, but were used to darken Casement's name (67).

A further book from 1940 centres on Casement and is written by H.W. GüntherFranken, a pseudonym of Walter Günther Schreckenbach, more generally a writer for children and a translator. The work is entitled Roger Casement: von England verraten - ein Leben für Irlands Freiheit (Roger Casement: Betrayed by England - A Life for Ireland's Freedom). The title indeed betrays much about the anti-British nature of this work of propaganda; a muddled mix of impressionistic biographical details of Casement's life, anti-British hysteria and paper thin arguments in favour of German colonialism. ${ }^{15}$ The tone of the text is established at the very beginning as the author writes: "With this publication, an attempt is made to recapture the actions of a man in danger of being forgotten, a man whose selfless commitment to Volk and Vaterland should be a glowing example for coming generations" (Günther-Franken 6). At a time of anti-British hysteria, Casement's memory was now being used as a tool to buttress aggressive and militaristic German nationalism. 
The most curious of the Casement Nazi-era texts is from Hanns Walther, the pseudonym of journalist and author Hans-Walter Gaebert, from 1942. It is a popular spy novel dealing with Casement's Irish nationalist life from 1914 to 1916, especially his time in America (Walther 7-76) and the so-called Findlay Affair and possible attempts to endanger Casement's life (159-190). Substantial part of the novel is also given to a fictional and tentative female German love interest (Walther 78-81;83-130), whom the character of Casement meets first in New York and with whom he later corresponds, but who, Casement finds out, eventually dies of typhus (211-213). In her fevered final delirium this love interest, Hilde von Lohde, only spoke of Casement, according to a letter the Casement character receives (Walther 212).

The novelist uses the Casement character's voice to attack the brutal and murderous British (Walther 11; 19; 20; and 21), while also praising well-administered German colonies in Africa (35); this at a time when much of Europe was now under the murderous Nazi German administration. One of Casement's main achievements, it is suggested, was to create the fear of an Irish invasion and, thus, bring troops away from the western front (Walther 207), while a degree of anti-Semitism is also in evidence as the judge at Casement's trial was Rufus Isaacs, "one of those Jews who believe they have to be more English than the English themselves" (278). The "Black Diaries", the novelist states, are the words of south American "Armando Normann [sic]" which Casement had reproduced himself for his own files, the Secret Service banished evidence of the real author in order to cast Casement as a person "inflicted with a perverted disposition" (Walther 280): thus England "vilified the great freedom fighter" (279). The novel utilises the entertainment elements of the thriller genre to create a fairly simplistic anti-British narrative that also implicitly offers a degree of justification for Nazi actions in World War Two.

\section{Post-War Germany: Using Casement to counteract Gay Stereotypes on Primetime Television}

Without the context of Anglo-German conflict, and attendant propaganda wars, depictions of Casement became sporadic in the direct post-War period in Germany. Some interest may definitely be seen in 1959, however. This was the year in which excerpts of the so-called "Black Diaries" were published in Paris and, as a consequence, the British government made the diaries available to researchers in the Public Record Office. An article in the Hamburg weekly magazine, Der Spiegel, catalogues the drama concerning the diaries, providing some historical context and a short summary of Casement's life. ${ }^{16}$

The most substantial depiction of Casement in this period, however, came in a television miniseries called Sir Roger Casement (Kugelstadt 1968) which appeared on consecutive nights - Wednesday and Thursday, 26 and 27 September 1968 - on ZDF; the second German national television station. At a time when German television-owners generally had two national and one regional television channel, the miniseries was likely to have had a relatively large viewership, not least due to its primetime slot at 8 o'clock in the evening. ${ }^{17}$ The actor Heinz Weiss played Casement. Weiss was then best known as the heroic FBI agent Phil Decker; a role he played in eight television movies from 1965 to 1969 (Weiss 81-84). The script was written by the Austrian popular history writer Hellmut Andics ${ }^{18}$ and his occasional writing partner Werner Murawski ${ }^{19}$, while direction was lead by Hermann Kugelstadt, who had cut his teeth as a director of sentimental and often comic Heimat films in the 1950s but who now generally made political documentaries for television.

The miniseries - two films of 90 minutes each - is called a Dokumentarspiel: a documentary play. It depicts, in at times complex detail, Roger Casement's life from 1911 to 
1916, including his two years in Germany. While the series places the German Imperial Empire as an agent within the Anglo-Irish conflict, it does this in a critical manner, showing the scepticism and suspicion with which Casement was held by the German military, and highlighting the lack of substantial help the Irish conspirators actually received. The series acknowledges indirectly Casement's importance as an international humanitarian, but concentrates on his Irish nationalism while also representing Casement sympathetically as a gay man.

The series shows the complex web of entangled agency involved in Irish nationalism at this time, with scenes set in New York, Philadelphia, Dublin, London, Oslo, Berlin, Limburg, Tralee and Ardfert, county Kerry. It also successfully represents the complexity of the various factions of Irish history, depicting in an explanatory manner Ulster unionism, constitutional nationalism, and both the romantic and pragmatic orientations within physical force Irish nationalism. Indeed, at times the narrative becomes overladen with detail, and retains often quite a didactic tone. This is evident, for example, in an early scene set in Dublin in 1912, when the actor playing Eoin McNeill, ostensibly in conversation with Heinz Weiss' Casement, explains to the viewers the political position and historical roots of Ulster unionism, complete with direct reference to a map of Ireland hanging on the wall.

The series does, however, successfully show the emotionality of Casement's isolation and lack of success in Germany. In a scene set in the Limburg prisoner of war camp, Casement seeks to persuade Irish prisoners to join a possible Irish Brigade. When the vast majority react in a negative manner, and state that they have fought the Germans and do not want to let their comrades in the British army down, the camera stays on the face of Weiss' Casement whose ineffectual pleading visibly turns to gravely disappointed misunderstanding. Some inaccuracies in detail are probably jarring to a contemporary viewer; for example scenes set in Tralee at the end of film two were very obviously filmed in a small German seaside town, while a number of Irish dancing scenes owe more to the Scottish Highlands than Ireland.

As already mentioned Sir Roger Casement also contains a clear and positive, if largely coded, representation of a heroic gay man; a first for a German narrative of Casement. The miniseries accepts unquestioningly the authenticity of the "Black Diaries". In one scene the Policeman Basil Thomson searches Casement's London residence for incriminating evidence. He comes across the diaries, saying that they show that Casement had "abnormal tendencies, tendencies towards young men" (Kugelstadt); the most direct and un-coded reference to homosexuality in the mini-series. This largely sympathetic representation is actually a fairly radical political and societal intervention, it is here argued, as the platform this takes place in - a midweek television movie - is moderate, conventional and mainstream, while, at this time in West Germany, gays and lesbians experienced extreme repression (Gammerl 8). Similar to other European cultural contexts, a medical discourse of "sickness", "deviance" and "perversion", dominated the discussion of gayness in Germany at this time (Gammerl 7). Direct state repression was due to the infamous paragraph 175 dating back to 1872 , which was loosely enforced during the Weimar period but then reinforced during the reign of the Nazis, resulting in gay people being sent to concentration camps. Amazingly, the post-war West German state, in the grip of the conservative Christian Democrats, maintained the Nazi version of this anti-gay law until 1969, when it was watered down for the first time. From 1949 until 1969 in West Germany police carried out raids on gay bars, making mass arrests, while men convicted of illegal gay acts faced prison sentences, with up to 60,000 gay men being imprisoned (Scally). Within this socio-cultural context the depiction of a heroic gay man on prime time television, beamed into a large number of sitting rooms, takes on substantial significance; an act of albeit fairly gentle defiance of this dehumanising state policy. 
When it comes to the representation of gays and lesbians in screen culture, Richard Dyer is the dominant critical voice in the English-speaking world. Dyer critiques two distinct ways in which gay stereotyping takes place in cinema: stereotyping through iconography, and stereotyping through structure. Stereotyping through iconography is seen as the use of "a certain set of visual and aural signs which immediately bespeak homosexuality" (Dyer 357). Dyer - perhaps being stereotypical himself - sees heterosexual relationships as involving "people defined as social unequals [sic]" (359); oppressor and oppressed, men and women, unlike homosexual relationships, which involve, he believes, two people who are equal in terms of "sex caste". The medium of film, however, rarely acknowledges this and seeks to recreate the inequality of heterosexual relationships through other forms of social inequality, such as age, class or wealth (Dyer 359). Dyer (362) is also, however, critical of attempts at depicting more rounded characterizations of gay figures, such as in the acclaimed Hollywood movie Dog Day Afternoon (1975). The very richness of such characterizations, he believes, set up against gay stereotypes, turns gayness into a personality issue requiring individual solutions, and makes it difficult to think of solidarity existing between the gay protagonist and the collective of his sex caste (Dyer 362).

Sir Roger Casement, in its depiction of the principal character, creates a rounded characterization of a gay protagonist, devoid of stereotyping of both iconography or structure, yet manages also to establish a sense of solidarity, a sense of community between Casement and a wider, though largely imagined, gay community. It does this in a coded yet relatively clear manner. This is most evident in a scene in which Casement and Arthur Conan Doyle discuss the famous case of Oscar Wilde in Casement's London apartment. The scene is composed as a character triangle with Casement standing beside a large portrait of Wilde, while Conan Doyle sits to the right of both figures in an armchair. At this point in the story the viewer has already learned from Basil Thomson of Casement's "tendencies towards young men" (Kugelstadt). The following discussion takes place:

Arthur Conan Doyle: Good old Oscar Wilde. He was, yes, a great writer, but was also, well, yes ... perhaps we may call it wayward [abwegig].

Roger Casement: Oh I can tell you of dozens among the greats of world history who were no different than him. Does it damage their work? I would almost say that what they are accused of appears to be inseparably connected with their genius. (Kugelstadt)

Thus, the character of Casement here identifies with and situates himself within a wider gay community that is associated with genius rather than stereotypes of iconography or structure. This sense of solidarity and community is also clearly visualised with direct reference to Oscar Wilde. It is an explicitly positive generalising of a wider, if imagined, gay community, marked actually by brilliance and virtuosity.

In a later scene, before Casement's trail, the character of Arthur Conan Doyle meets the Archbishop of Canterbury in order to ask him for his support in a wider campaign for leniency for Casement. The Archbishop tells Doyle, however, that he cannot support Casement due to the diaries and the "ugly suspicion" he is under. Thus, while earlier talking of gayness in a coded and quasi-medical manner, the Doyle character now takes a humanistic position in relation to an actual gay person; his very real friend Roger Casement. By rejecting Doyle, the Archbishop acts in an inhumane manner, as Doyle asks him: "You, the head of the Anglican Church, are not going to argue for a man's life?" (Kugelstadt) The scene is also critical of the Christian Churches' position in relation to gay men and women: a potent force in West Germany at this time. The series also retains elements of a thriller and it is noticeable 
that the principle characters utilising a quasi-medical discourse when describing Casement are the Policeman Basil Thomson and Casement's prosecutor, Frederick Smith. Both are depicted in a distinctly villainous light. They both refer to Casement as being, for example, an "unfortunate, sick person" or a "sickly-inclined person" (Kugelstadt).

\section{Post Unification Germany: Being Gay is being Selfless?}

Casement also appears in W.G. Sebald's Die Ringe des Saturn, originally published in 1995. Sebald, who died in a car crash in 2001, established himself as a unique voice in German literature with his genre-defying work. Die Ringe des Saturn is, ostensibly, a travel diary of a journey through Suffolk, but Sebald's travels serve as a springboard for melancholy-tinged episodes on European cultural history and biography. One of these episodes deals with Casement, whom Sebald sees in relation to the author Joseph Conrad. Casement selflessly highlights the plight of the oppressed in the Congo and South America (Sebald 154-156), and from there proceeds to what Sebald calls "the white Indians of Ireland" (157). The German author then provides a greatly distilled account of Irish history, telling his readers that Oliver Cromwell killed nearly half of the Irish population and then, in a retelling of the discredited "Irish slaves" myth, Cromwell sent thousands of Irish men and women as slaves to the West Indies (157). Sebald believes, erroneously, that the authenticity of Casement's diaries has now, in 1995, been proven beyond doubt. For him, the principal conclusion to make regarding Casement at this stage is that it was "possibly because of Casement's homosexuality" that he was able to go "beyond the borders of societal classes and races" and to recognise the "repression and exploitation" enacted on those who were far from the centres of power (162). Thus, Casement's status as a societal outsider had an enabling function and fed into, and was possibly intertwined with, his selflessness; at least according to Sebald's eccentric biographical fragment in his travel book that is not really a travel book.

Mario Vargas Llosa's novel based on the life of Roger Casement was translated into German and released in 2011. While the book's reception in the media was mixed, the three consistently dominating narrative strands of Casement's life, international humanist, Irish nationalist, and gay man, were aired together by journalists. ${ }^{20} 2016$ and the commemoration of the 1916 Rising, including the capture and execution of Roger Casement, also received some media attention in Germany. Interestingly, journalists composing articles relating to Casement appeared here to choose their specific Casement. Thus, for example, a liberal journalist depicted Casement as the "Irish human rights activist" (Rach), a Berlin-based leftwing journalist wrote of Casement as an Irish nationalist who dreamt a "Berlin dream of Irish freedom" (Conrad), while the gay magazine Männer saw him as a gay revolutionary who was a victim of the "societal homophobia of the time" (Clarke). Aidan Dunne's argument that "different factions draw from the complex layers of his history and character a Casement who suits their own preferences and prejudices" (Dunne) seems apposite here.

\section{Conclusion}

There is, thus, a tradition of producing narratives of Casement's life in Germany. Perhaps this would be best understood as a plurality of narrative traditions, dependent on the sociopolitical context and the needs of the creators. As we have seen, Casement has been depicted as a rabid Irish nationalist within anti-British propaganda texts, but also as an international humanitarian who practiced a liberationist nationalism, while the Casement story has, in addition, been mined to humanise gay men in post-War West Germany. The multifaceted nature of the Casement story, its very flexibility, has thus been an undoubted factor in its popularity and appropriation by German storytellers. There is also an Anglophile strain in 
German culture, which some scholars see as having its roots in the Enlightenment (Maurer). Casement, with his sense of fair play and equality, may feasibly be situated within this liberal German Anglophile tradition; the fact that he eventually rejects this culture also provides his story with an interesting sting in the tail. The Casement story is in addition a distinctly German chapter of Irish history and perhaps, for this reason, an attractive entrance into the history of another country. The first substantial German Casement narrative of the 21st century has still to be written. Hopefully it will assemble Casement's diverse threads into a thrilling story.

\section{Notes}

${ }^{1}$ Taking only recent biographically oriented studies into account, books have appeared by Mitchell (2014; and 2003), Laubscher (2010), Goodman (2009), Ó Síocháin (2008), Inglis (2002), and Dudgeon (2002).

${ }^{2}$ John Banville's script for the later project may be viewed here: John Banville, "Casement: An Original Screenplay". http://breac.nd.edu/articles/casement-an-original-screenplay/ [retrieved 21/03/2017].

${ }^{3}$ Irische Blätter was the official organ of the Deutsch-Irische Gesellschaft, the German-Irish Society, which consisted of a number of German academics friendly to Ireland, politicians from the Deutsche Zentrumspartie (the German Centre Party) - then the most important arm of German political Catholicism - and some Irish or Irish-Americans based in Germany. The journal looked to inform its readership about the situation in Ireland, but was often propagandist and anti-British in tone; especially during the war years. The full history of the GermanIrish Society has yet to be written. According to Lerchenmueller (171) the German-Irish Society published 41 volumes of Irische Blätter from April 1917 to December 1920, while it was financed from moneys made available by influential Centre Party politician Matthias Erzberger (who was later assassinated by far-right Freikorps members in 1921). Leading members of the German-Irish Society included Georges Chatterton-Hill, Irish-American John Gaffney; who had been US consulate in Munich until 1915, Berlin historian Eduard Meyer; brother of influential Celtic Studies scholar Kuno Meyer, and Celtic Studies scholar Julius Pokorny. According to Lerchenmueller (xi) Irish and Irish-Americans in the German-Irish Society - who saw themselves as Irish republicans - actually worked closely with elements from monarchist, anti-republican national-conservative German circles. For more on Julius Pokorny see: O’Dochartaigh (2003).

${ }_{5}^{4}$ All translations are by the author.

5 According to Franz Fromme's Wikipedia entry Fromme, a journalist and academic involved in the völkischnationalist movement who published widely on Ireland, Belgium and Sweden, was the translator of Casement's writings. See: https://de.wikipedia.org/wiki/Franz_Fromme_(Schriftsteller,_1880) [retrieved 28/03/2017].

${ }^{6}$ See: "Vorwort der Übersetzter zur ersten Auflage". Roger Casement. Gesammelte Schriften. Munich: Huber, 1917. 1-2, 1.

7 See: "Nachwort". Gesammelte Schriften. 239-247, 240.

${ }^{8}$ See: "Nachwort". 244.

${ }^{9}$ See: "Nachwort". 246.

${ }^{10}$ Casement is described as "possessing something of the manner of St. Francis of Assisi. Nature was important to him, people were everything" (15). Rothenfelder writes of him being "the saint of the Irish Volk" (26) and "a saint of seraphic love" (51). Rothenfelder tells his readers of an episode at the Bavarian mountain pilgrimage at Andechs, which apparently Casement had visited with a student friend. Casement spies two Bavarian peasants walking up the mountain with heavy baskets on their backs, and decides that he and his friend will carry these up the mountain instead. While this is easy for Casement, "the giant" (24), the student cannot do it and Casement pays a local, strong man to carry the second basket instead. "It was testament to Casement's wonderful, deeply religious love of people, which had voluntarily carried a cross on its back" (24).

${ }^{11}$ Spindler writes that Casement hated England "bis aufs Blut"; literally "into his blood" (17).

12 Mitchell believes that the "understanding of Casement's internationalism" was "greatly amplified" by Olden's book ("A Strange" 12).

${ }^{13}$ In 1939 Weiland also produced a German translation of Irish nationalist (and Stuart's mother-in-law) Maud Gonne-MacBride's autobiography, A Servant of the Queen, while she later also translated works by John Buchan, Elizabeth Bowen and Philip Larkin.

${ }^{14}$ Stuart, whose texts were translated by Weiland, provides a nationalist and anti-British introduction and a text on Eamon de Valera; the Celtic Studies professor Ludwig Mühlhausen delivers a chapter on Douglas Hyde; Weiland writes on Maud Gonne MacBride, the mysterious Nora O'Mara (see: O'Donoghue 104) has a chapter on Padraig Pearse, while the even more mysterious Vincent Coyle writes on Charles Stuart Parnell. See: Weiland (1940) 
${ }^{15}$ The author writes of Casement's exposure of immense cruelty in the Belgian Congo, something he believes "under a German colonial administration would not have been possible", yet the Versailles Treaty does not allow Germany to retain colonies (Günther-Franken 43). The author, thus, fails to mention the German mass murder of the Herero in Namibia, then German South-West Africa, from 1904 to 1908. See e.g. Zimmerer (2003).

${ }^{16}$ The author of the article is not named. See: "England: Die schwarzen Tagebücher". Der Spiegel. 19 August 1959.

17 The German television magazine Bild und Funk recommended Sir Roger Casement to its readers as one of eight highlights of the television week. See here: Bild und Funk. 21 September 1968.

${ }^{18}$ Andics was an author, journalist and scriptwriter who wrote history books for non-experts. His books included works on Jewish life in Vienna and the women of the Habsburg dynasty. See: "Hellmut Andics gestorben", www.wienerzeitung.at/nachrichten/kultur/medien/381085_Hellmut-Andics-gestorben.html, accessed 12 August 2016. Andics, whose mother was Jewish, became a social democrat at a young age and his writing leaned towards the left. See: Winter (2014).

${ }^{19}$ Information concerning Murawski is less forthcoming. He was a scriptwriter and also a producer for ZDF and the Hamburg-based production company Aurora. Murawski later also co-wrote, with Andics, the television film Gnade für Timothy Evans/Mercy for Timothy Evans, concerning a miscarriage of justice and an incorrect execution for murder in England. See: www.filmportal.de/person/wernermurawski_od61a659391946e2a365b074foabb157, accessed 12 August 2016.

${ }^{20}$ See for example: Funck (2011); Worthmann (2011) and Fanizadeln (2011).

\section{Works Cited}

Banville, John. "Casement: An Original Screenplay". 2016. 21 March 2017. http://breac.nd.edu/articles/casement-an-original-screenplay/

Bild und Funk. 21 September 1968.

Chatterton-Hill, Georges. "Gedanken zum Todestage Roger Casements". Irische Blätter 1.5 (August 1917): 318-332.

Bullet, Agatha M. Roger Casement and India. Stockholm: Dahlberg, 1917.

Casement, Roger. Gesammelte Schriften. Munich: Huber, 1917.

Clarke, Kevin. "Posthume Wiedergutmachung 2016?”. Männer. 1 January 2016. 28 March 2017. http://m-maenner.de/2016/01/gehaengt-wegen-homophobie/

Conrad, Andreas. "Osteraufstand vor 100 Jahren: Der Berliner Traum von der Irischen Freiheit”. Tagesspiegel. 28 March 2016. 28 March 2017. http://www.tagesspiegel.de/berlin/osteraufstand-vor-100-jahren-der-berliner-traumvon-der-irischen-freiheit/13369668.html.

Curry, Charles E. "Preface". Sir Roger Casement's Diaries: His Mission to Germany and the Findlay Affair. Ed. Charles E. Curry. Munich: Arche, 1922. 11-16.

Dudgeon, Jeffrey. Roger Casement: The Black Diaries - With a Study of His Background, Sexuality and Irish Political Life. Belfast: Belfast press, 2002.

Dudgeon, Jeffrey. "Casement Wars". Dublin Review of Books. April 2013. 20 March 2017. http://www.drb.ie/essays/casement-wars.

Dudgeon, Jeffrey. "Roger Casement: Controversies in Script and Image". Paper given 22 April 2013, Queen's University Belfast. 20 March 2017. https://www.academia.edu/5819866/Roger_Casement_Controversies_in_Script_and_I mage.

Dunne, Aidan. "The Blank Canvas of Roger Casement's Life". Irish Times. 9 June 2016. 9 June 2016. http://www.irishtimes.com/culture/art-and-design/visual-art/the-blankcanvas-of-roger-casement-s-life-1.2677023?

Dyer, Richard. "Stereotyping". Media and Cultural Studies. Ed. Meenakshi Gigi Durham and Douglas Kellner. Malden, MA, Oxford and Victoria: Blackwell, 2006. 275-282. 
"England: Die schwarzen Tagebücher". Der Spiegel. 19 August 1959. 12 August 2016.www.filmportal.de/person/wernermurawski_od61a659391946e2a365b074foabb 157.

Fanizadeh, Andreas. "Mario Llosas neuer Roman: Schwul und very Irish". Tageszeitung. 9 September 2011. 28 March 2017. http://www.taz.de/!5112373/

Funck, Gisa. "Geschichte eines tragischen Weltverbesserers". Deutschland Funk, 2 October 2011. 28 March 2017. http://www.deutschlandfunk.de/geschichte-eines-tragischenweltverbesserers.700.de.html?dram:article id=85254

Fromme, Franz. "Roger Casement”. Irische Freiheitskämpfer. Berlin: Scherl, 1940. 53-67.

Gammerl, Benno. "Eine Regenbogengeschichte". Aus Politik und Zeitgeschichte 15.6 (2010): 3-7.

Goodman, Jordan. The Devil and Mr. Casement: One Man's Struggle for Human Rights in South America's Heart of Darkness. London: Verso, 2009.

Günther-Franken, H.W. Roger Casement: von England verraten - ein Leben für Irlands Freiheit. Berlin: F. Osmer, 1940.

"Hellmut Andics gestorben". $12 \quad$ August 2016. www.wienerzeitung.at/nachrichten/kultur/medien/381085_Hellmut-Andics gestorben.html.

Inglis, Brian. Roger Casement. London: Penguin, 2002.

Kugelstadt, Hermann. Sir Roger Casement. Germany: ZDF, 1968.

Ó Síocháin, Séamus. Roger Casement: Imperialist, Rebel Revolutionary. Dublin: Lilliput Press, 2008.

Laubscher, Michael. Who is Roger Casement? Dublin: History Press, 2010.

Lerchenmueller, Joachim. Keltischer Sprengstoff: Eine wissenschaftsgeschichtliche Studie über die deutsche Keltologie von 1900 bis 1945. Tübingen: Max Niemayer, 1997.

Lucy, Anne. " 'Highly Sexualized'. Roger Casement Dance Show Sparks Outrage in Kerry”. Irish Examiner, 27 July 2016. 21 March 2017. http://www.irishexaminer.com/ireland/highly-sexualised-roger-casement-dance-showsparks-outrage-in-kerry-412542.html.

Maurer, Michael. Aufklärung und Anglophilie in Deutschland. Göttingen: Vandenhoeck und Ruprecht, 1987.

McClancy, Malcolm. "The Casement Sonata by Gavin Friday Review: The Curve of Words". Irish Times. 26 August 2016. 26 August 2016. http://www.irishtimes.com/culture/books/the-casement-sonata-by-gavin-fridayreview-the-curve-of-words-1.2769401?

McCormack, W.J. Blood Kindred: W.B. Yeats - The Life, The Death, The Politics. London: Pimlico, 2005.

Mitchell, Angus. Casement. London: Haus, 2003.

Mitchell, Angus. " 'A Strange Chapter of Irish History': Sir Roger Casement, Germany and the 1916 Rising". Field Day Review 8 (2012): 4-21.

Mitchell, Angus. Roger Casement. Dublin: O’Brien Press, 2014.

Mitchell, Angus. "Roger Casement and the History Question". History Ireland 24.4 (July/August 2016): 34-37.

O’Dochartaigh, Pól. Julius Pokorny, 1887-1979: Germans, Celts and Nationalism. Dublin: Four Courts Press, 2003.

O'Donoghue, David. Hitler's Irish Voices: The Story of German Radio's Wartime Irish Service. Belfast: Beyond the Pale, 1998.

Olden, Balder. "Mein Leben". Paradiese des Teufels: Biographisches und Autobiographisches - Schriften und Briefe aus dem Exil. Ed. Ruth Greuner. Berlin 
(East): Rütten and Loening, 1977. 7-8.

Olden, Balder. "Paradiese des Teufels". Paradiese des Teufels: Biographisches und Autobiographisches - Schriften und Briefe aus dem Exil. Ed. Ruth Greuner. Berlin (East): Rütten and Loening, 1977. 81-215.

Pokorny, Julius. "Meine Errinerungen an Sir Roger Casement". Irische Blätter 1.2 (May 1917): 93-96.

Rach, Ruth. "Irische Menschenrechtsaktivist Roger Casement: Tödlicher Kampf für Gleichberechtigung”. 3 August 2016. 28 March 2017. http://www.deutschlandradiokultur.de/irischer-menschenrechtsaktivist-rogercasement-toedlicher.932.de.html?dram:article_id=361937.

Rasche, Hermann. "From Laragh to Berlin: Francis Stuart and his Time in Germany". Creative Influences: Selected Irish-German Biographies. Ed. Joachim Fischer and Gisela Holfter. Trier: Wissenschaftlicher Verlag, 2009. 77-88.

Rothenfelder, Franz. Casement in Deutschland. Augsburg: Reichel, 1917.

Scally, Derek. "Germany to Rehabilitate Gay Men Convicted in post-War Era". Irish Times. 11 May 2016.

Sebald, W.G. Die Ringe des Saturn. Frankfurt: Fischer, 2007.

Spindler, Karl. Das geheimnisvolle Schiff. Berlin: August Scherl, 1921.

Stuart, Francis. Der Fall Casement: Das Leben Sir Roger Casements und der Verleumdungsfeldzug des Secret Service. Trans. Ruth Weiland. Hamburg: Hanseatische Verlagsanstalt, 1940.

TV Hören und Sehen. 21 September 1968.

Walther, Hanns. Gewitter über Irland: Roger Casements Opfergang. Leipzig: Bohn und Sohn, 1942.

Weiland, Ruth, ed. Irische Freiheitskämpfer. Berlin: Scherl, 1940.

Weiss, Heinz. Logbuch meines Lebens. Munich: Gryphon Edition, 2003.

Winter, Renée. Geschichtspolitiken und Fernsehen: Repräsentationen des Nationalsozialismus im frühen österreichischen TV (1955-1970). Bielefeld: Transcript, 2014.

Worthmann, Merten. "Gut geölt, aber ohne Herzblut". Süddeutsche Zeitung. 12 September 2011. 28 March 2017. http://www.sueddeutsche.de/kultur/neuer-roman-desliteraturnobelpreistraegers-llosa-gut-geoelt-aber-ohne-herzblut-1.1142101.

Zimmerer, Jürgen. "Krieg, KZ und Völkermord in Deutsch-Südwestafrika: Der erste deutsche Genozid". Völkermord in Deutsch-Südwestafrika: der Kolonialkrieg (1904-1908) in Namibian and seine Folgen. Ed. Jürgen Zimmerer and Joachim Zeller. Berlin: Links, 2003. 45-63.

Received: 03 April 2017 Revised version accepted: 17 October 2017

Fergal Lenehan teaches Intercultural Studies at the Frierich-Schiller-University of Jena. He has published two monographs, Intellectuals and Europe (2014) and Stereotypes, Ideology and Foreign Correspondents: Ireland in German Media, 1946-2010 (2016).

fergal.lenehan@uni-jena.de 